\title{
Efficacy of Chitosan/propolis Liquid Extract Emulsion Coating on Refrigerated Storage Quality of Crayfish Meat
}

mehmet ÇOBAN ( $\sim$ mzcoban@firat.edu.tr)

Fırat University

\section{Research Article}

Keywords: Chitosan coating, Edible coating, Propolis, Emulsion, Crayfish (Astacus leptodactylus)

Posted Date: December 14th, 2020

DOl: https://doi.org/10.21203/rs.3.rs-125230/v1

License: () (i) This work is licensed under a Creative Commons Attribution 4.0 International License.

Read Full License 


\section{Abstract}

In this study, the efficiency of chitosan-propolis liquid extract coatings on the storage quality of crayfish meat at $4{ }^{\circ} \mathrm{C}$ was studied. With respect to the treatments, chitosan at $2 \%(\mathrm{w} / \mathrm{v})$ in $1 \%(\mathrm{v} / \mathrm{v})$ of glycerol is dissolved and then emulsified with propolis liquid extract at 0.3 and $0.6 \%(\mathrm{v} / \mathrm{v})$. The control and treated samples were analyzed periodically for chemical $(\mathrm{pH}$, Thiobarbituric acid, Peroxide value, Total volatile basic nitrogen and $\mathrm{K}$ values), microbiological (Total aerobic mesophilic bacteria, Psychrotrophic bacteria H2S-producing bacteria, Yeasts- Moulds) and sensorial attributes (Odor, Taste, Firmness and Overall acceptance) along storage. Results demonstrate that chitosan coatings containing propolis liquid extract are effective in controlling the growth of bacteria and chemical indices. These results can be beneficial for seafood processing sectors, as well as for food technologists.

\section{Introduction}

Astacus leptoductylus are commonly found in lakes, ponds and riversr in Turkey and low-fat, low-calorie and rich in protein. However, it is susceptible to spoilage just like fish and other seafood and should be consumed fresh immediately after harvest, or measures should be taken to preserve their original freshness as much as possible. Therefore, adequate packaging technologies need to be developed for the preservation of fish or other foods (Ojagh et al., 2010; Bahadır Koca and Argun Uzunmehmetoğlu, 2018 ).

Edible film or coatings are materials placed on the surface of foods by spraying and dipping that are obtained from natural resources and can be consumed with the food. They have been among the most popular packaging materials in recent years since they only require a simple production technology, are low cost, are obtained from natural components, have diverse functional features, and are biodegradable. The coatings control moisture, oxygen, carbon dioxide, lipid, flavour, and aroma transfer by functioning as a mass transfer barrier between the food and the atmosphere surrounding the food. Chitosan based films/coatings are a widely used coating in food products, which can extend the shelf life of a product and provide microbial safety for consumers. The number of microorganisms on the surface of foods can be controlled by adding preservative materials or materials such as antioxidants to edible coatings (Dursun and Erkan, 2009; Korkmaz, 2018).

Synthetic preservatives are reported to delay the lipid peroxidation process and increase the shelf life of foods. But, the synthetic additives can be affected consumer health, so consumers are tend to avoid foods prepared with chemical preservatives (Yazgan et al., 2020). Propolis is a natural product collected by honeybees from plants especially flowers and buds. Withal, it is included in the GRAS list and is used as a bioactive food Even though the composition of propolis changes depending on its source, it generally consists of $50 \%$ resin, $30 \%$ wax, $10 \%$ essential and aromatic oils, $5 \%$ pollen, $5 \%$ other organic compounds and mineral substances supplement. The main active ingredients of propolis are benzoic acid, cinnamic acid, phenols, ketophenols, hydroquinone, rcoumarins and naphthalene (Galeotti et al., 2018). 
Some researchers have reported that propolis can be used as a natural antioxidant and antimictobial in meat and fish products (Gutierrez-Cortes and Suarez Mahecha, 2014; Hascik et al., 2015; Uçak, 2018). Moreover, the many studies have reported that chitosan films or coatings enriched with plant extracts or essential oils improve the quality and shelf life of foods (Fan et al., 2019; Cai et al., 2018; Shahbazi and Shavisi, 2018; Fadıloğlu and Emir Coban, 2018). However, according to our literature seek, there is not found any information on the application of propolis liquid extract/chitosan coating to crayfish meat. Therefore, the this study was planned to evaluate the effect of chitosan/propolis liquid extract emulsion coating on the storage quality and shelf life of crayfish (Astacus leptoductylus) meat.

\section{Materials And Methods}

\section{Materials}

Chitosan (medium molecular weight: 190 - $310 \mathrm{kDa}$; deacetylation degree: 75 - 85\%, viscosity of 200$800 \mathrm{cPs}$ ) and Tween-80 were purchased from Sigma-Aldrich. Propolis liquid extract ( $\geq 98 \%$, food-grade, FDA approved) was obtained from a commercial company (Talya herbal product Co.,Turkey). All other reagents were procured in analytical grade.

\section{Preparation of chitosan coating-forming emulsions}

$\%$ 2'lik (w / v) kitosan,\% 1 gliserol içinde hazırlandı ve manyetik bir karıştırıcı ile 2 saat $30^{\circ} \mathrm{C}$ de karıştıııldı. Daha sonra, propolis sıvı özütü, kitosan çözeltisine\% 0,3 ve 0,6 (h / h) oranında ayrı ayrı ilave edildi. (Sun vd., 2019; Zhou vd., 2019). Bu karışım 20000 rpm'de 1 dakika süreyle emülsifiye edildi ve ardından yüksek basınçlı bir valf homojenleştiriciden (Panda 2K homojenleştirici, NS1001L, GEA Niro Soavi, Parma, Italya) 200 bar üç geçişle emülsifıye edildi.

\section{Preparation sample treatments}

A total of $5 \mathrm{~kg}$ of live Crayfish in the same size $(8-9 \mathrm{~cm})$ obtained from Keban Dam Lake in Elazığ were transferred to the laboratory under aseptic and cold conditions in $1 \mathrm{~h}$. They were washed with tap water and boiled for 10 minutes at $100^{\circ} \mathrm{C}$. After boiling, crayfishes were cooled and separared from shells. The deshelled crayfish were randomly divided into four groups: Cont (uncoated), Ch, Ch- $0.3 \%$ PLE and Ch$0.6 \%$ PLE. The crayfish were individually immersed in the coating solutions for $2 \mathrm{~min}$ (crayfish/coating solution ratio: 1/3). Then, the coated crayfish were dried for $1 \mathrm{~h}$ in a cold air cabinet set at $10^{\circ} \mathrm{C}$ to form the edible coating and were stored at $4^{\circ} \mathrm{C}$. All samples were separately packed in a sterile polyethylene bag and stored for 16 days (Figure 1). The present study was conducted as two parallels.

\section{Chemical analysis}


Ten grams crayfish meat were homogenized in $100 \mathrm{~mL}$ of sterile distilled water. The $\mathrm{pH}$ was measured in triplicate at room temperature, according to the method reported by Gokalp et al. (2001). The total volatile base nitrogen (TVB-N) value was determined by using a automatic kjeldahl apparatus according to microtitration methodology reported by Gharibzahedi and Mohammadnabi (2017). The TVB-N value was stated as $\mathrm{mg} / 100 \mathrm{~g}$ fish muscleThe thiobarbituric acid (TBA) value was measured using the method reported by Kilic and Richards (2003). Spectrophotometric measurements were made based on the principle of malondialdehyde in samples to react with TBA reagent. The TBA values were described as $\mathrm{mg} \mathrm{MDA} / \mathrm{kg}$ seafood flesh. The PV value was assigned using the method of Shantha and Decker (1994). $2 \mathrm{~g}$ sample was mixed in $30 \mathrm{ml}$ chloroform-glacial acetic acid solution (chloroform / glaciel acetic acid, 3/2). Then $1 \mathrm{ml}$ of saturated potassium iodide (KI) solution was added and mixed again. Subsequently, it was kept in the dark for 5 minutes, and $75 \mathrm{ml}$ of pure water and $1 \mathrm{ml}$ of starch solution were added and titrated with $0.1 \mathrm{M}$ sodium thiosilphate $(\mathrm{Na2S} 2 \mathrm{O3})$ solution. The K-value were determined using a HPLC method (a Merck-Hitachi Model D-6500). The extraction procedure was based on that by Fan et al. (2008).

\section{Microbiological analysis}

Ten grams of crayfish meat were taken, transferred aseptically to a sterile stomacher bag containing 90 $\mathrm{ml}$ of buffer peptone water, and mixed for 1 min using a Stomacher blender (Lab Stomacher Blender 400BA 7021 Seward Medical, UK). Then, decimal dilutions (1:10, diluent: $0.1 \%$ peptone water) were prepared and inoculated on agar plates to determine:

(a) the total mesophilic aerobe bacteria (TMAB) and psychrotrophic bacteria (PB) counts on pour plates of plate count agar incubated for 2 days at $30^{\circ} \mathrm{C}$ and 10 days at $5{ }^{\circ} \mathrm{C}$, respectively;

b) $\mathrm{H} 2 \mathrm{~S}$-producing bacteria count assigned using iron agar plates incubated for 2 days at $30^{\circ} \mathrm{C}$;

c) yeasts and moulds determined using potato dextrose agar (PDA) and incubated for 5 days at $22^{\circ} \mathrm{C}$. All counts were expressed as log CFU/g (Halkman, 2005).

\section{Sensory evaluation}

The sensorial attributes of crayfish meat were determined according to the method reported by Cai et al. (2015). Seven experienced panelists measured important quality parameters, such as odour, taste, firmness, and overall acceptable using ten-grade hedonic score system about crayfish meat : $10.0-9.0$ (excellent), $8.9-7.0$ (good), $6.9-4.9$ (fair) and $3.0-1.0$ (rejectable).

\section{Statistical evaluation}


The IBM SPSS $\circledast 26$ (SPSS Inc., Chicago, IL, USA) statistical package was used for data processing. The statistical significance of the differences between the groups and storage days of the chemical and microbiological data determined as a result of the analyses carried out in the study was determined using variance analysis. All experiments were replicated two times for all groups (ANOVA).

\section{Results And Discussion}

\section{Chemical Quality}

$\mathrm{pH}$ of the crayfish meat used in this study was 5.72. In all groups, the $\mathrm{pH}$ value reduced at first but then increased throughout storage (Fig. 2a). The reason reduced in the $\mathrm{pH}$ value of samples can be caused by the formation of lactic acid from glycogen in fish muscles (Manju et al., 2007; Fan et al., 2008). In contrast, the rising in $\mathrm{pH}$ value was reported to be adhere to the release of protein metabolites, like ammonia and tri-methylamine by the activity of deterioration bacteria. While for the ch coatings containing propolis liquid extract samples, the $\mathrm{pH}$ value observed was low compared to control samples during the storage period $(p<0.05)$. Furthermore, lower $\mathrm{pH}$ changes were determined in the $\mathrm{Ch}+0.3 \% \mathrm{PE}$ and $\mathrm{Ch}+0.6 \% \mathrm{PE}$ samples. It can be deduced that the lower $\mathrm{pH}$ values of the $\mathrm{Ch}+0.3 \% \mathrm{PE}$ and $\mathrm{Ch}+0.6 \%$ $\mathrm{PE}$ samples combined with chilling could increase microbial prevention and cause prolongation of the quality of crayfish meat (Abd El-Halim El-Sherif and Abd El-Ghafour, 2015)

Alterations in the TVB-N of the samples with storage are demonstrated in Fig. 2b. Coated groups demonstrated a tendency of decreasing TVB-N value throughout the first 4 days of storage. Subsequently, a rise was determined until the end of storage. These results were also similar to the findings of other researchers. The rise in TVB-N value was particularly clear in Control and Ch crayfish samples, on the other hand, crayfish samples with Ch + PLE coatings supplemented with PLE significantly decreased the value of TVB-N during storage. Gimenez et al. (2002) reported a value of $25 \mathrm{mg} / 100 \mathrm{~g}$ fish meat as the beginning of spoilage. In this study, TVB-N values remained below this limit of admissibility until at the end of storage in Ch + PLE coated groups, meanwhile, the limit of admissibility was exceeded on day 8 and day 12 for control and group coated with Ch, respectively. These conclusions are in parallel with the findings of Martínez-Álvarez et al., (2008) ,Tsironi et al. (2009) and Nekuie Fard et al., 2015. Ojagh et al. (2010) declared that chitosan coatings combined with cinnamon oil effectively suppress the rise in TVB$\mathrm{N}$ value and protect refrigerated rainbow trout fillets.

The changes in the PV of all the groups during chilled storage are presented in Fig. $2 \mathrm{~d}$. At the start of the storage period, the PVs were determined as $0.96,0.90$, and 0.92 meqO $_{2} / \mathrm{kg}$ for the crayfish coated with $\mathrm{Ch}, \mathrm{Ch}+0.3 \% \mathrm{PLE}$ and $\mathrm{Ch}+0.6 \% \mathrm{PLE}$, respectively. The PV increased during storage time, as awaited, the control group had the highest PV values and PV might be significantly affected $(p<0.05)$ by PLE concentration in the coating solutions; however, which were lower than that of $\mathrm{Ch}+0.3 \% \mathrm{PE}$. Similar results were also revealed for the yellowfin tuna meat (Thunnus albacares) coated with chitosan/lemon peel extract (Sabu et al., 2020) who mentioned that supplemented coating with lemon peel extract was efficient in restraining the formation of lipid oxidation products. A study conducted by Viji et al (2015) 
determined similar findings in Indian mackerel coated with a combination of citrus peel and mint leaf extracts.

The variations in the TBA value of crayfish coated along storage time are indicated in Figure. $2 \mathrm{c}$. The initial TBA values were in the range of $0.52 \pm 0.12$ to $0.44 \pm 0.07 \mathrm{mg} \mathrm{MDA} / \mathrm{kg}(p<0.05)$; however, the TBA values increased as gradually until the end of storage time in all groups. This increase was slower observed in crayfish samples coated with Ch containing PLE when compared with other samples $(p<$ 0.05). Similar results were reported by Thaker et al. (2017), Fadıloğlu and Çoban (2018) and Sun et al. (2019), in meat and fish coated with coatings containing essential oil. After day 12 , the control group and there were no significant differences among the Ch group $(p>0.05)$. According to these results, propolis extract might be used for delay lipid oxidation in the active coatings for shellfish and fish products. Yu et al.(2017) reported that the chitosan coating combined with essential oils (clove, cinnamon and lemon grass) have strong antioxidant activities and preservative effects for antioxidant enzyme activities.

The fresh crayfish used in this study had an initial $\mathrm{K}$ value of $11.35 \%$. In all the groups, the $\mathrm{K}$ value rose during storage at $4{ }^{\circ} \mathrm{C}$ (Fig. 2e). The $\mathrm{K}$ value of the untreated crayfish and Ch group exceeded the maximum acceptable limit on days 8 and 12, respectively. While for theCh $+0.3 \%$ PLE and $\mathrm{Ch}+0.6 \%$ PLE groups, the $\mathrm{K}$ value remained low for the acceptable limit on day 16 . The maximum permissible level for the $\mathrm{K}$ value is $60 \%$ (Ehira and Uchiyama, 1974) According to these results, it might be supposed that the $\mathrm{Ch}+\mathrm{PLE}$ coatings prohibited the degradation of ATP and keep quality of crayfish during refrigerated storage. Similar results were reported by Liu et al. (2019) for crayfish coated by a gelatin-containing red pitaya peel methanol extract. Song et al. (2011) also described a similar result for bream.

\section{Microbiological Quality}

The total mesophilic aerobe bacteria (TMAB) of all groups at $4{ }^{\circ} \mathrm{C}$ at the end of storage is presented in Fig. 3a. The microbial count of all groups rises progressively with storage time. In accordance with the International Standards (ICMSF, 1986), the maximum admissible limit of TMAB in raw fish is 7 log CFU/g. In the present study, the first TMAB count of crayfish was $3.22 \log$ CFU/g. On day 4, the TMAB in all groups was below 5 log CFU/g; however, on day 12 the control group reached a count of $8.40 \mathrm{log} \mathrm{CFU} / \mathrm{g}$. This count was greater than the maximal admissible limit of ICMSF. According to these results, the control group had a microbiological shelf life of 8 days.

The main microorganisms that cause spoilage of fish and fish products stored in cold conditions are gram-negative psychrophilic bacteria. As displayed in Fig. 3b, the rise in the psychrotrophic bacteria (PB) count in the control group was greater than in the coated groups. Initially, the psychrotrophic bacteria count was $2.88 \mathrm{log} \mathrm{CFU} / \mathrm{g}$, which increased to $8.00 \mathrm{log} \mathrm{CFU} / \mathrm{g}$ at day 20 of the storage for control groups. While the psychrotrophic bacteria counts for groups coated with 0.3 and $0.6 \%$ PLE containing were 6.12 and $5.40 \log \mathrm{CFU} / \mathrm{g}$, at the end of storage. Similar results were found in studies for chitosan/cinnamon oil and fish gelatine/GL-BCD-curcumin for fresh fish protection (Jouki et al., 2014; Sun et al., 2019). 
The varieties of H2S-producing bacteria (Fig. 3c), yeast and mould bacteria (Fig. 3d) and Pseudomonas spp. bacteria (Fig. 3e) populations indicated a similar tendency with TAMB and psychrophilic bacteria. On day 20, groups coated with Ch containing PLE obtained lower counts.

\section{Sensorial Quality}

The sensory evaluation results are shown in Fig. 4. At the beginning of the storage, a glossy and smooth layer of Ch-based coatings was seen on the crayfish sample surfaces, resulting in increased scoring. Therefore, the sensory score of the control group was lower than the coated groups $(p<0.05)$. With the progress of storage, the sensory scores of all groups decreased. A faster decrease was detected in the control group $(p<0.05)$. Control and Ch were reported inadmissible by the panelists in terms of odour and taste on day 12 and day 16 , respectively. Also, $\mathrm{Ch}+0.6 \%$ PLE group even on day 16 were considered to be consumable by panelists. These data suggest that $0.6 \%$ of PLE concentration is more effective in $\mathrm{Ch}$ based coatings. This result is also compatible with the chemical and microbiological results.

\section{Conclusion}

The incorporation of propolis liquid extract into a crayfish chitosan coating increased the effectiveness of the coating. Ch + PLE treatment increased the crayfish shelf life by $\sim 7$ days compared to the control group. Chemical, microbiological and sensorial analyses showed that the $\mathrm{Ch}+0.6 \% \mathrm{PLE}$ coating had an obvious effect on the quality of crayfish $4^{\circ} \mathrm{C}$ storage and their shelf lives. Therefore, PLE combined with coatings might be useful as a safe natural protective for seafood.

\section{References}

1. Abd El-halim El-Sherif, S.A.E.H and Abd El-Ghafour, S. 2015. Nutritive value of canned River Nile Crayfish (Procambarus clarkii) products. The Egyptian Journal of Aquatic Research. vol.41, no.3, p. 265-272. https://doi.org/10.1016/j.ejar.2015.06.002.

2. Bahadır Koca, S., Argun Uzunmehmetoğlu, E. 2018. Interactions of season, sex and size on nutrient composition of freshwater crayfish (Astacus leptodactylus Eschscholtz, 1823) from Lake Eğirdir. Food Sci. Technol. Campinas. vol.38 no.Suppl.1, p. 44-49. https://doi.org/10.1590/1678457x.15817

3. Cai, L., Cao, A., Bai, F., Li, J. 2015. Effect of $\varepsilon$-polylysine in combination with alginate coating treatment on physicochemical and microbial characteristics of Japanese sea bass (Lateolabrax japonicas) during refrigerated storage. LWT Food Sci. Technol. vol.62, p. 1053-1059. https://doi.org/10.1016/j.Iwt.2015.02.002

4. Cai, L., Leng, L., Cao, A., Cheng, X., Li, J. 2018. The effect of chitosan-essential oils complex coating on physicochemical, microbiological, and quality change of grass carp (Ctenopharyhgodon idella) fillets. J Food Saf. vol.38, no.1, p. e12399.https://doi.org//10.1111/jfs.12399 
5. Dursun, S., Erkan, N. 2009. The use of edible protein films in seafood. Journal of FisheriesSciences.com. vol.3, no. 4, p. 352-373. https://doi.org/10.3153/jfscom.2009040.

6. Ehira, S., Uchiyama, H.1974. Freshness lowering rates of cod and sea-bream viewed from changes in bacterial count, total volatile base and trimethyl amine-nitrogen and ATP related compounds. Bull. Japan. Soc. Sci. Fish. vol.40, no.5, p. 479-487.https://doi.org/10.2331/suisan.40.479

7. Fadıloğlu, E.E., Emir Çoban, Ö. 2018. Effects of chitosan edible coatings enriched with sumac on the quality and the shelf- life of rainbow trout (Oncorhynchus mykiss, Walbaum, 1792) fillets. J Food Safety. vol.38, no.6, p. e12545.https://doi.org/10.1111/jfs.12545

8. Fan, W., Chi, Y., Zhang, S. 2008. The use of a tea polyphenol dip to extend the shelf life of silver carp (Hypophthalmicthys molitrix) during storage in ice. Food Chem, vol. 108, no. 1, p. 148-153. https://doi.org/10.1016/j.foodchem.2007.10.057

9. Fan, W., Sun,J Chen, Y., Qiu,J., Zhang, Y.,Chi, Y. 2019. Effects of chitosan coating on quality and shelf life of silver carp during frozen storage Food Chemistry. vol. 115, p. 66-70. http://doi.org/10.1016/j.foodchem.2008.11.060

10. Galeotti, F., Maccari, F., Fachini, A., Volpi, N. 2018. Chemical composition and antioxidant activity of propolis prepared in different forms and in different solvents useful for finished products. Foods. vol. 7, no.(3), p. 41. http://doi.org/10.3390/foods7030041

11. Gharibzahedi, S.M.T., Mohammadnabi, S. 2017. Effect of novel bioactive edible coatings based on jujube gum and nettle oil-loaded nanoemulsions on the shelf-life of Beluga sturgeon fillets. Int. J. Biol. Macromol. vol.95, p. 769-777.https://doi.org/10.1016/j.ijbiomac.2016.11.119

12. Gimenez, B., Roncales, P., Beltran, J.A. 2002. Modified atmosphere packaging of filleted rainbow trout. J Sci Food Agric,vol. 82, no. 10, p. 1154-1159.https://doi.org/10.1002/jsfa.1136

13. Gokalp, H.Y., Kaya, M., Zorba, O., Tulek, Y.2001. Quality control and laboratory practice guidelines in meat and meat products. Ataturk University Agriculture Faculty Publications. Erzurum, Turkey.

14. Gutierrez-Cortes, C., Suarez Mahecha, H. 2014. Antimicrobial activity of propolis and its effect on the physicochemical and sensoral characteristics in sausages. Vitae. vol. 21, no.2, p. 90-96.

15. Halkman AK. 2005. Merck Food Microbiology Applications, Başak Publications, Ankara,Turkey.

16. Hascík, P., Elimam, I. O., Krocko, M., Bobko, M., Kacniova, M., Garlík, J., Saleh, A. A. 2015. The influence of propolis as supplement diet on broiler meat growth performance, carcass body weight, chemical composition and lipid oxidation stability. Acta Universitatis Agriculturae et.Silviculturae Mendelianae Brunensis. vol. 63, no.2, p. 411-418.http://doi.org/10.11118/actaun201563020411

17. ICMSF (International Commisson on Microbiological Spescifications for Foods). (1986):

Microorganisms in Foods 2. sampling for microbiological analysis, 2nd edition, University of Toronto Press, Toronto.

18. Jouki, M., Yazdi, F.T., Mortazavi, S.A., Koocheki, A., Khazaei, N.2014. Effect of quince seed mucilage edible films incorporated with oregano or thyme essential oil on shelf life extension of refrigerated rainbow trout fillets. Int J Food Microbiol, vol.174, p. 8897.https://doi.org/10.1016/j.ijfoodmicro.2014.01.001 
19. Kilic, B., Richards, M.P.2003. Lipid oxidation in poultry Doner Kebabi pro-oxidative and anti-oxidative factors. J. Food Sci., vol.68, p. 690-696.https://doi.org/10.1111/j.1365-2621.2003.tb05732.x

20. Korkmaz, F. 2018. Edible films-coatings and the use in aquaculture. Atatürk Üniv. Ziraat Fak. Derg, vol. 49, no. 1, p. 79-86. https://doi.org/10.17097/ataunizfd.333596.

21. Liu, W., Shen, Y., Li, Na., Mei, Jun., Jing, Xie. 2019. Application of gelatin Incorporated with red pitaya peel methanol extract as edible coatingfor quality enhancement of crayfish (Procambarus clarkii) during refrigerated storage. J. Food Qual. ID 1715946, p. 8.https://doi.org/10.1155/2019/1715946

22. Manju, S., Jose, L., Srinivasa Gopal, T.K., Ravishankar, C.N., Lalitha, K.V.2007. Effects of sodium acetate dip treatment and vacuum-packaging on chemical, microbiological, textural and sensory changes of Pearlspot (Etroplus suratensis) during chill storage. Food Chem, vol. 102, no. 1,p. 27-35. https://doi.org/10.1016/j.foodchem.2006.04.037

23. Martínez-Álvarez, Ó., Gomez-Guillen, M.D.C., Montero, P. 2008. Chemical and microbial quality indexes of Norwegian lobsters (Nephrops norvegicus) dusted with sulphites. Int. J. Food Sci., vol.43, p. 1099-1110. https://doi.org/10.1111/j.1365-2621.2007.01576.x

24. Nekuie Fard, A., Seidgar, M., Azadikhah, D. 2015. The study of frozen Astacus leptodactylus tail fillet quality changes. AACL Bioflux. vol.8, p. 6.

25. Ojagh, S.M., Rezaei, M., Razavi, S.H., Hosseini, S.M.H. 2010. Effect of chitosan coatings enriched with cinnamon oil on the quality of refrigerated rainbow trout. Food Chem, vol.120, no.1,p. 193-198. https://doi.org/10.1016/j.foodchem.2009.10.006

26. Sabu, S., Ashita, T., Stephy, S. 2020. Chitosan and lemon peel extract coating on quality and shelf life of yellowfin tuna (Thunnus albacares) meat stored under refrigerated condition. Indian J. Fish., vol.67, no.1, p. 114-122. https://doi.org/10.21077/ijf.2019.67.1.91361-15

27. Shahbazi, Y., Shavisi, N. 2018. Chitosan coatings containing mentha spicata essential oil and zinc oxide nanoparticle for shelf life extension of rainbow trout fillets, Journal of Aquatic Food Product Technology, 27:9, 986-997.http://doi.org/10.1080/10498850.2018.1518945

28. Shantha, N.C., Decker, E.A.1994. Rapid, sensitive, iron-based spectrophotometric methods, or determination of peroxide values of food lipids. Journal of AOAC International, vol.77, p. 421-424. https://doi.org/10.1093/jaoac/77.2.421

29. Song, Y., Liu, L., Shen, H., You, J., Luo, Y.2011. Effect of sodium alginate-based edible coating containing different anti-oxidants on quality and shelf life of refrigerated bream (Megalobrama amblycephala). Food Control, vol.22, no.3-4,p. 608615.https://doi.org/10.1016/j.foodcont.2010.10.012

30. Sun, X., Guo, X., Ji, M., Wu, J., Zhu, W., Wang, J., Cheng, C., Chen, L., Zhang, Q.2019. Preservative effects of fish gelatin coating enriched with CUR/ $\beta C D$ emulsion on grass carp (Ctenopharyngodon idellus) fillets during storage at $4{ }^{\circ} \mathrm{C}$. Food Chem, vol.272,no. 30, p. 643652.https://doi.org/10.1016/j.foodchem.2018.08.040

31. Thaker, M., Hanjabam, M.D., Gudipati, V., Kannuchamy, N.2017. Protective effect of fish gelatin-based natural antimicrobial coatings on quality of Indian salmon fillets during refrigerated storage. J. Food 
Process Eng, vol. 40, no.1, p.e12270.https://doi.org/10.1111/jfpe.12270

32. Tsironi, T., Dermesonloouglou, E., Giannakourou, M., Taoukis, P. 2009. Shelf life modelling of frozen shrimp at variable temperature conditions. LWT-Food Science and Technology, vol.42, p. 664671.https://doi.org/10.1016/j.Iwt.2008.07.010

33. Uçak, I. 2018. Determınatıon of the lıpıd oxıdatıon levelın fısh oıl enrıched wıth propolıs extract. GIDA, vol.43, no.3, p. 523-532. http://doi.org/10.15237/gida.GD18031

34. Viji, P., Binsi, P. K., Visnuvinayagam, S., Bindu, J., Ravishankar, C. N. and Gopal, T. K. S. 2015. Efficacy of mint (Mentha arvensis) leaf and citrus (Citrus aurantium) peel extracts as natural preservatives for shelf life extension of chill stored Indian mackerel. J. Food Sci. Technol., vol.52, p. 6278-6289. https://doi.org/10.1007/s13197-015-1788-1

35. Yazgan, H., Burgut, A., Durmuş, M., Koske, A.R.2020. The impacts of water and ethanolic extracts of propolis onvacuum packaged sardine fillets inoculated with Morganella psychrotolerans during chilly storage. J Food Saf. vol.40 p. e12767. https://doi.org/10.1111/jfs.12767.

36. Yu, D., Xu, Y., Jiang, Q., Xia, W. 2017. Effects of chitosan coating combined with essential oils on quality and antioxidant enzyme activities of grass carp (Ctenopharyngodon idellus) fillets stored at 4 ${ }^{\circ} \mathrm{C}$. International Journal of Food Science and Technology. vol. 52, p. 404-412. https://doi.org/10.1111/ijfs.13295

37. Zhou, Q., Li, P., Fang, S., Liu, W., Mei, J., Xie, J. 2019. Preservative effects of gelatin active coating enriched with eugenol emulsion on chinese seabass (Lateolabrax maculatus) during Superchilling ($\left.0.9^{\circ} \mathrm{C}\right)$ Storage. Coatings, vol.9, p. 489.https://doi.org/10.3390/coatings 9080489 .

\section{Figures}




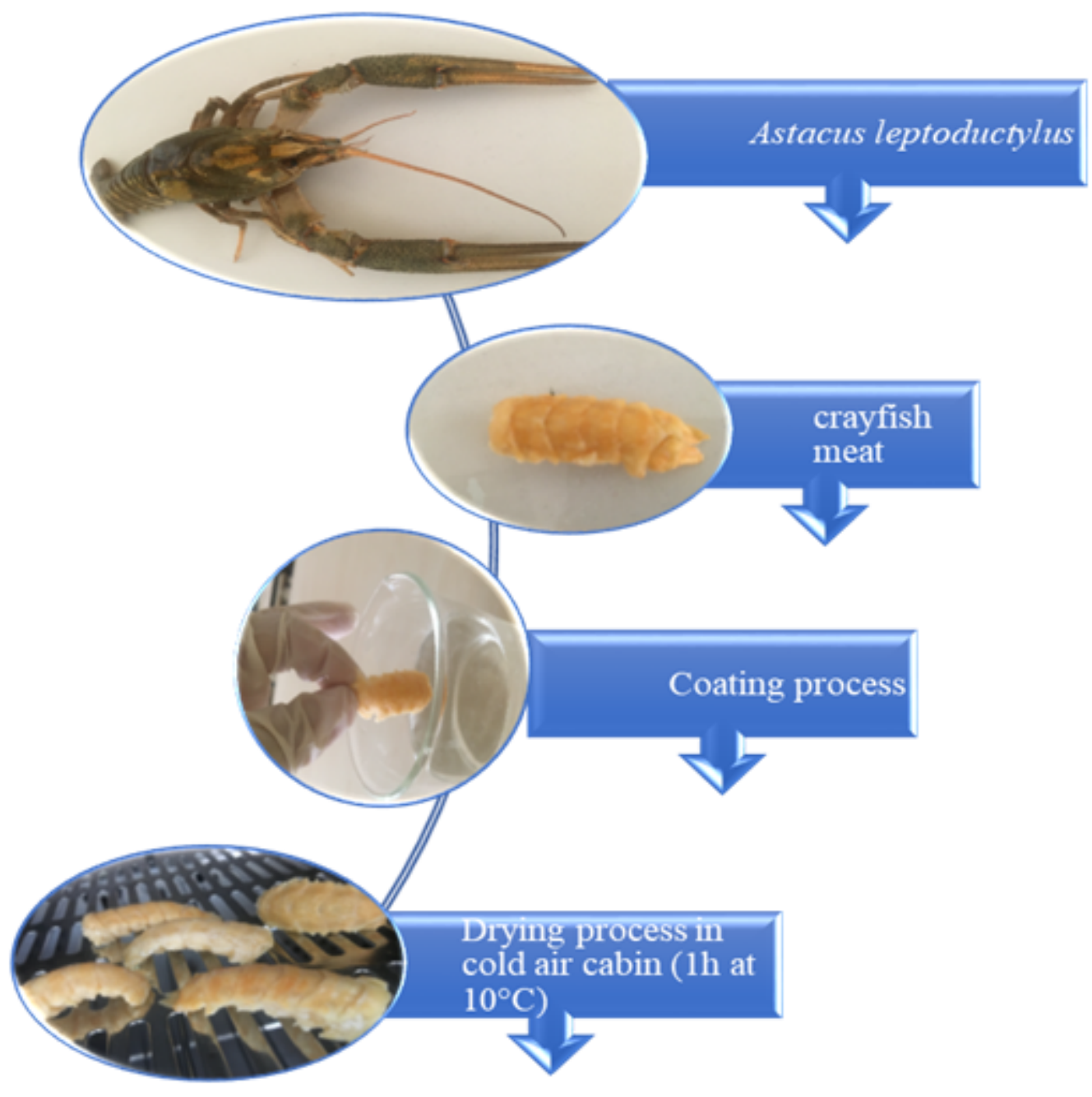

Figure 1

Flow diagram of coating processing with chitosan/propolis liquid extract emulsions of Crayfish meat 
a

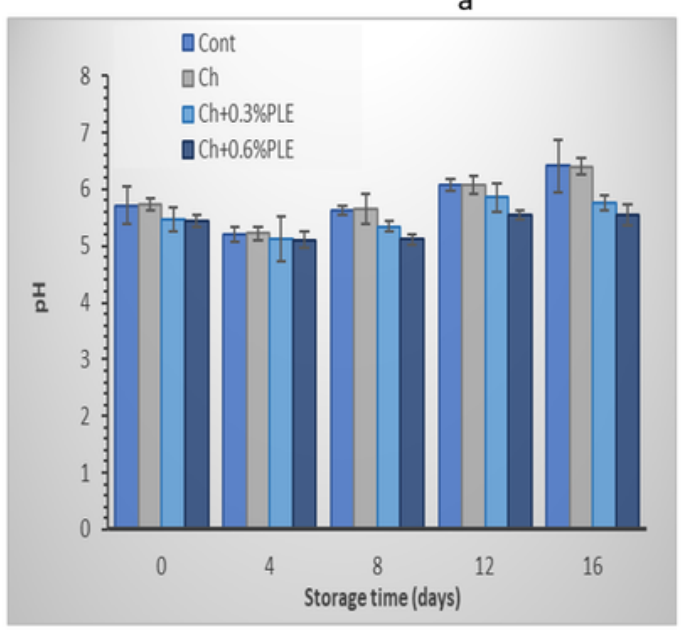

C

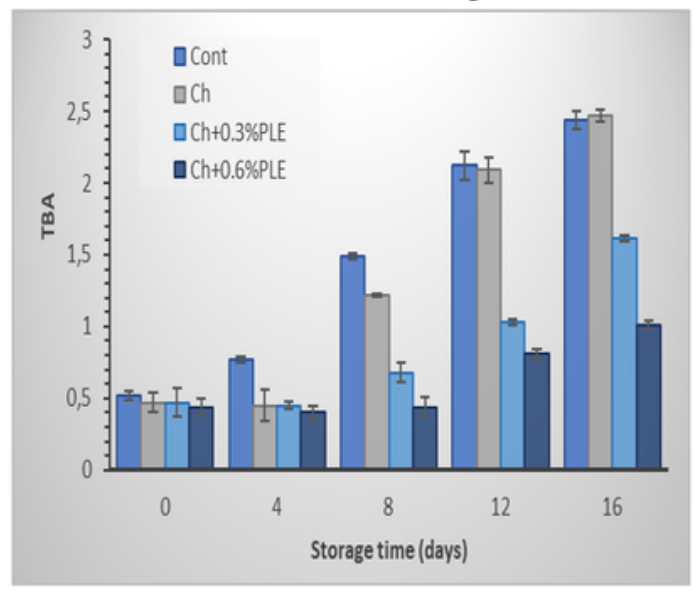

$\mathrm{e}$

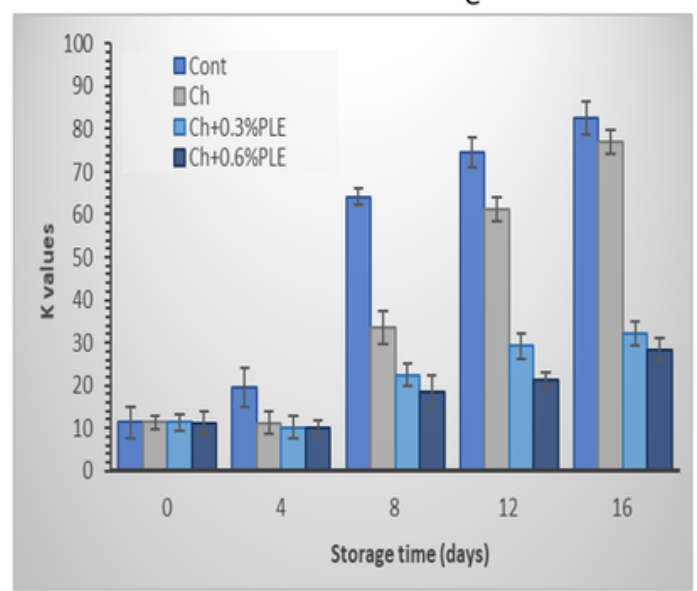

b

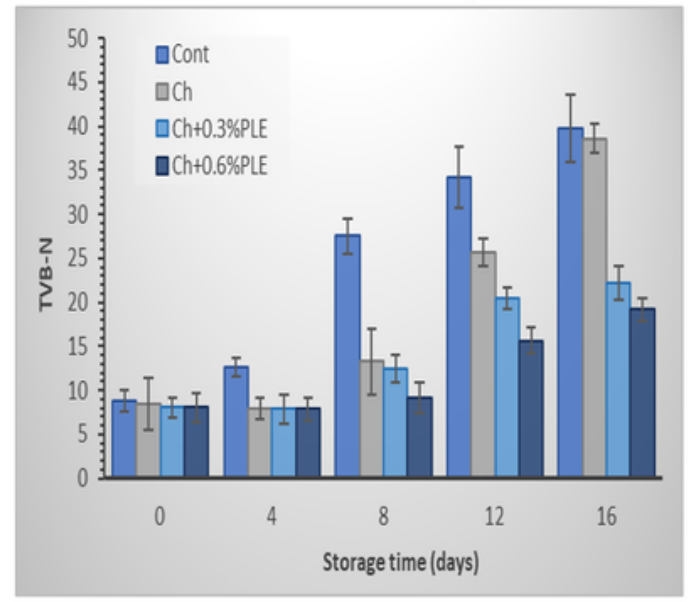

d

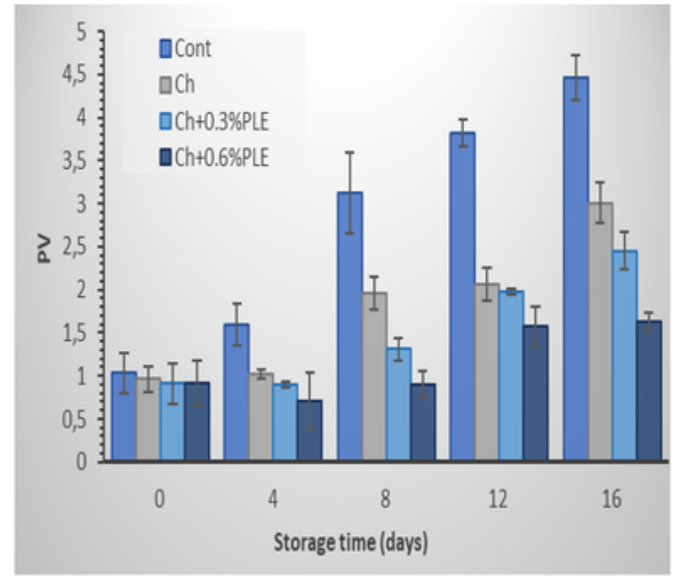

\section{Figure 2}

Changes in chemical quality a) Ph, b) TVB-N, c) TBA, d)PV and e) K-value crayfish coated with Ch coatings throughout storage at $4^{\circ} \mathrm{C}$. (Cont: without coated; Ch: coated with Chitosan; Ch+0.3\% PLE: coated with Chitosan $+0.3 \%$ Propolis liquid extract; $\mathrm{Ch}+0.6 \%$ PLE: coated with Chitosan $+0.6 \%$ Propolis liquid extract) 

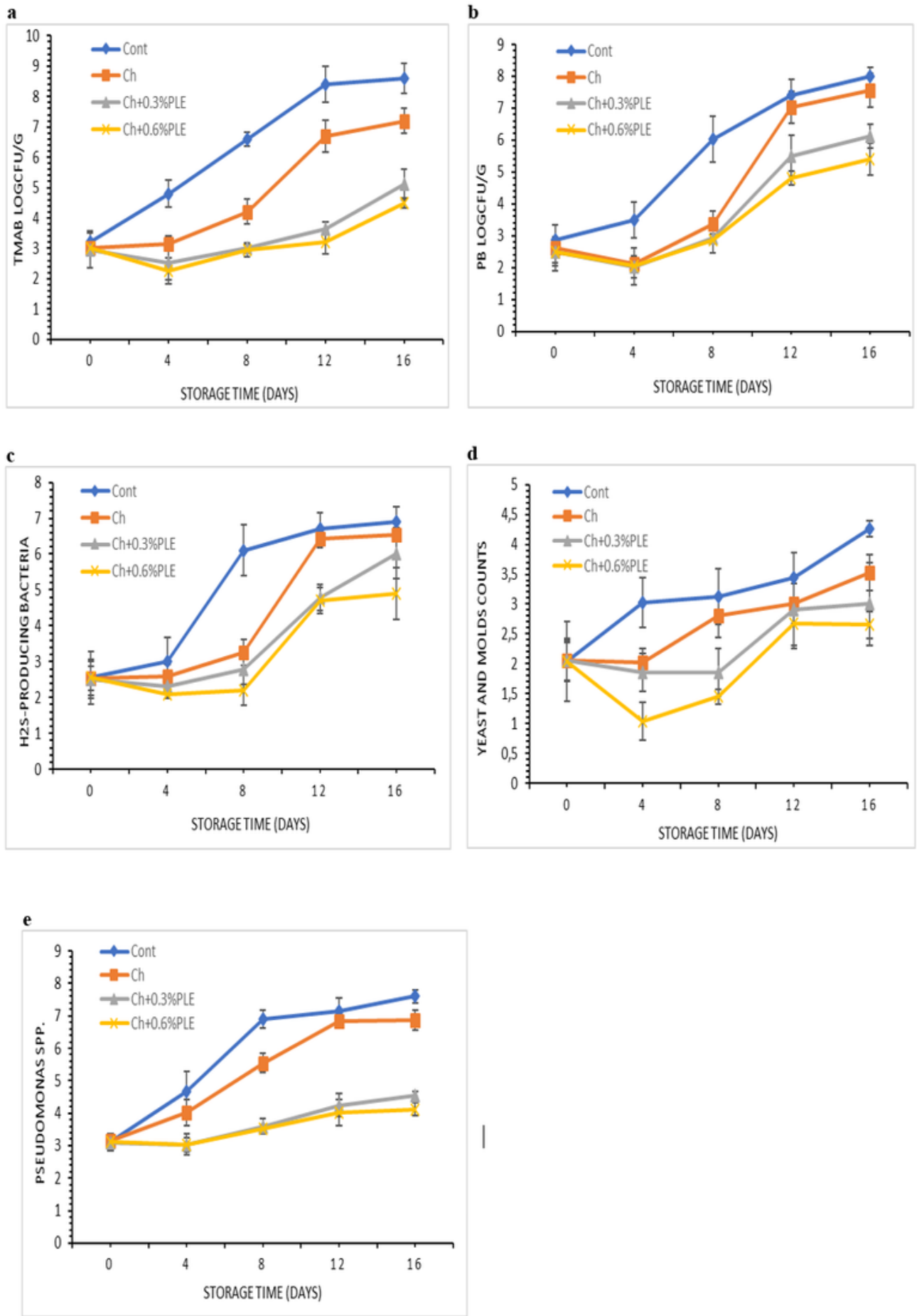

\section{Figure 3}

Changes in microbial quality a) TMAB, b) PB, c) H2S, d) Yeast-Mold and e) Pseudomonas spp. crayfish coated with Ch coatings throughout storage at $4{ }^{\circ} \mathrm{C}$. (Cont: without coated; Ch: coated with Chitosan; $\mathrm{Ch}+0.3 \%$ LE: coated with Chitosan $+0.3 \%$ Propolis liquid extract; $\mathrm{Ch}+0.6 \%$ PLE: coated with Chitosan $+0.6 \%$ Propolis liquid extract) 
a

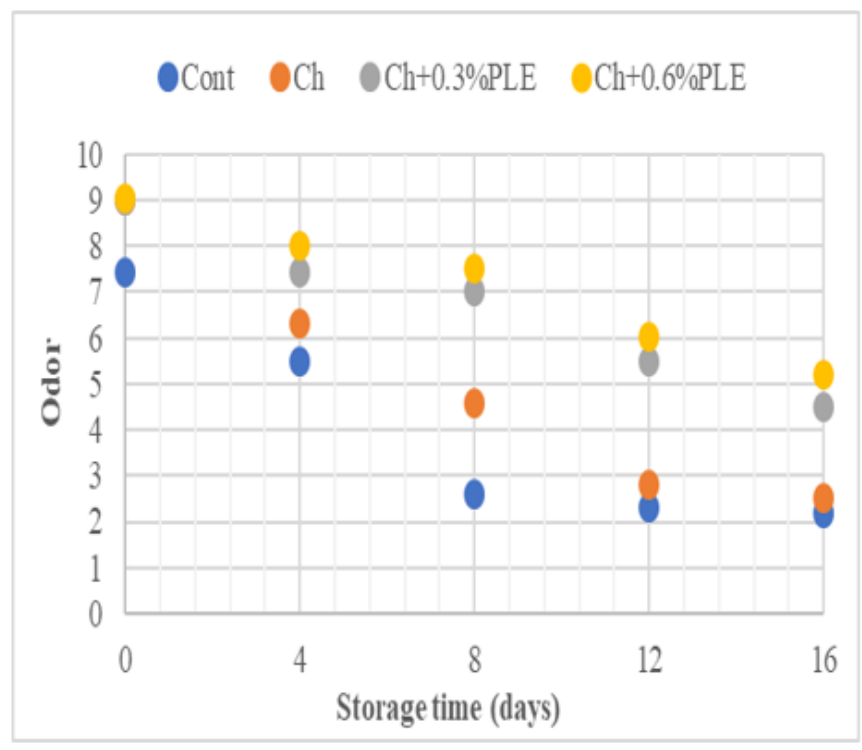

C

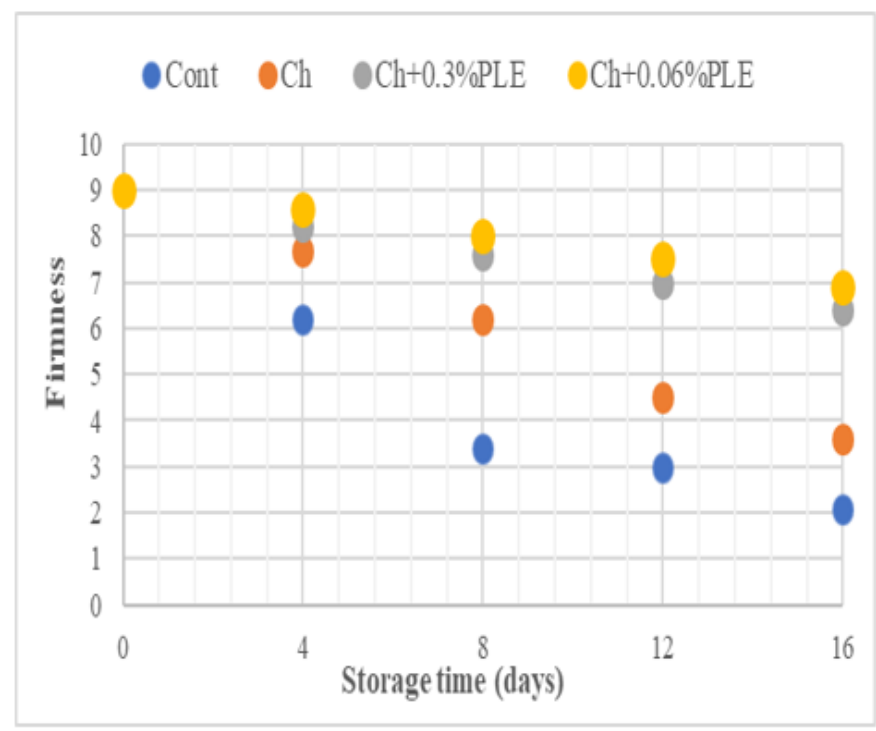

b

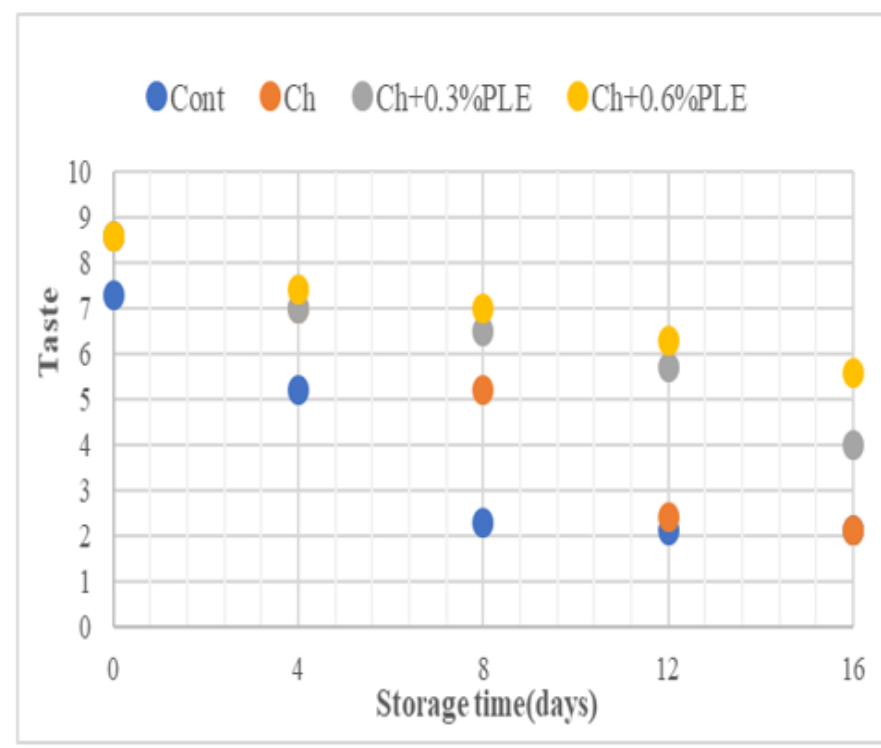

d

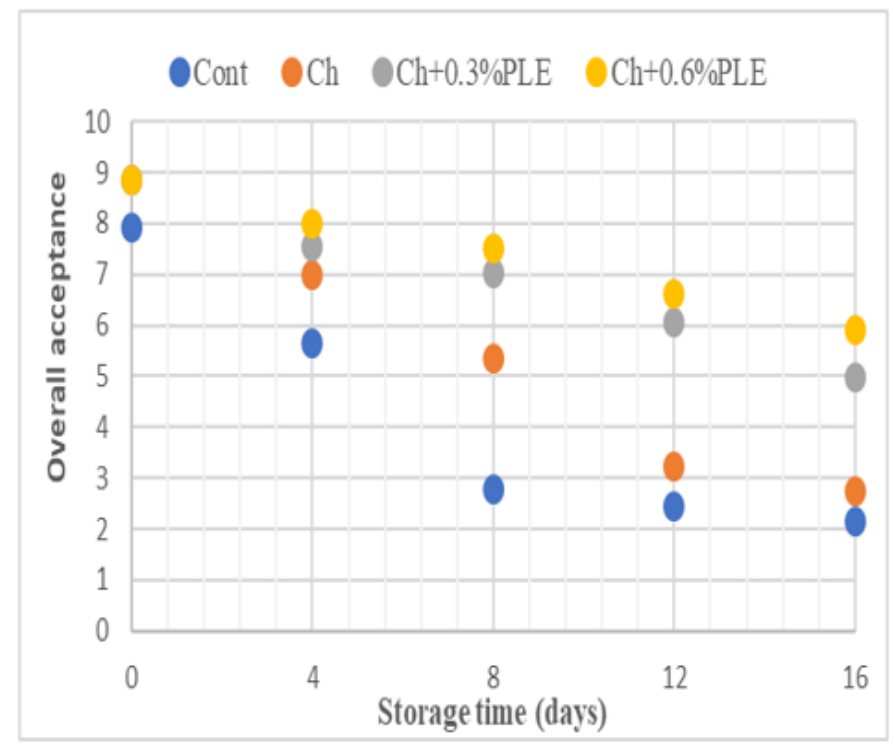

\section{Figure 4}

Changes in sensorial quality a) Odor, b) Taste, c) Firmness and d) Overall acceptance of crayfish coated with Ch coatings throughout storage at $4{ }^{\circ} \mathrm{C}$. (Cont: without coated; Ch: coated with Chitosan; Ch+0.3\% PLE: coated with Chitosan+0.3\% Propolis liquid extract; $\mathrm{Ch}+0.6 \%$ PLE: coated with Chitosan+0.6\% Propolis liquid extract) 